\title{
Morphospecies and taxonomic sufficiency of benthic megafauna in scientific bottom trawl surveys
}

\author{
Anik Brind'Amour ${ }^{a, *}$, Pascal Laffargue ${ }^{a}$, Jocelyne Morin $^{b}$, Sandrine Vaz ${ }^{c}$, Aurélie Foveau ${ }^{d}$, \\ Hervé Le Bris
}

\footnotetext{
a Ifremer, Département Ecologie et Modèles pour l'Halieutique, Rue de l'île d'Yeu, B.P. 21105, 44311 Nantes Cedex 03, France

b Ifremer, Laboratoire Ressources Halieutiques, Avenue du Général de Gaulle, 14520 Port-en-Bessin, France

${ }^{c}$ Ifremer, Ressources Halieutiques, 150 quai Gambetta - BP 69962321 Boulogne-sur-Mer, France

d CRESCO - IFREMER, Laboratoires Environnement Littoral \& Ressources Aquacoles Finistère - Bretagne Nord, Station de Dinard, 38 Rue du Port Blanc BP 7013435801 DINARD Cedex FRANCE

e Université Européenne de Bretagne, Agrocampus Ouest, UMR 985 Ecologie et Santé des Ecosystèmes, 65 rue de St. Brieuc, CS 84215, 35042 Rennes, France
}

*: Corresponding author : Anik Brind'Amour, tel.: +33 240374160 ; fax: +33 240374175 ; email address : Anik.Brindamour@ifremer.fr

\begin{abstract}
:
Scientific fisheries surveys routinely identify a large diversity of commercial and non-commercial benthic megainvertebrates that could provide useful information for Marine Strategy Framework Directive (MSFD) descriptors. Species is obviously the basic taxonomic level to which most ecological studies and theories refer. Identification at this level of organization is indeed always preferred over any other taxonomic level. Nevertheless, aggregation of species to higher taxonomic levels may be unavoidable sometimes, since errors of identification are known or suspected to occur in many surveys. Using analyses of taxonomic sufficiency (identification of organisms at various taxonomic resolutions) and groups of morphospecies (taxa identified easily by non-experts on the basis of evident morphological traits), this study aims to quantify the loss of ecological information incurred by partial identification of benthic megafauna in bottom trawl surveys in order to put such data to good use. The analyses were conducted on five scientific surveys representing a large range of geographical areas (from $150 \mathrm{~km}^{2}$ to $150000 \mathrm{~km}^{2}$ ) and environmental conditions. Results show that genus, family and, particularly, morphospecies are good surrogates for species identification in community analyses. We suggest that bottom trawl surveys can provide reliable megafauna data that may usefully complete those obtained by grab surveys. The use of morphospecies could lead to new strategies, combining different datasets to provide indicators for MSFD descriptors (e.g. D6).
\end{abstract}

\section{Highlights}

This study quantifies the ecological loss of misidentifying benthic megafauna. It suggests that the morphospecies is a good surrogate to species identification. Bottom-trawl surveys provide reliable data to inform MSFD benthic descriptors.

Keywords : Bay of Biscay ; English Channel ; North Sea ; Taxonomic sufficiency ; Benthic descriptor ; Bottom trawl surveys 


\section{Introduction}

The main objective of the Marine Strategy Framework Directive (MSFD; 2008/56/EC) is to achieve or maintain good environmental status (GES) by 2020. To fulfil MSFD requirements, 11 qualitative descriptors and a suite of indicators associated with each descriptor have been selected (Rice et al., 2012). European Member States have already initiated the reviews required to provide information for these descriptors and the estimation of the related indicators that will be used to assess the GES (Borja et al., 2011; Rombouts et al., 2013). Among the MSFD descriptors, D6, which concerns Sea Floor Integrity, and three others (D1, D2 and D4) include indicators that refer directly or indirectly to macro- and megainvertebrates (EC, 2010).

In a recent report on the Sea Floor Integrity descriptor (D6), Rice et al. (2010) underlined that most time series and established monitoring programs of benthos are conducted relatively nearshore and have restricted spatial coverage. These authors called for new strategies to assess environmental status of the sea floor integrity at regional or sea-wide scales. Scientific bottom trawl surveys dedicated to stock assessment of bentho-demersal fish populations routinely identify commercial and non-commercial benthic macro- and megainvertebrates. These annual surveys often cover large geographic areas (e.g. the North Sea) and could thus be used as a complement to grab surveys in order provide more complete information for MSFD descriptors. Data collected from bottom trawl surveys are available rapidly, as the sizes of the invertebrates collected allow a rapid identification that can be mostly done at sea. This is a considerable advantage over grab samples, which are usually washed through 1 or 2 $\mathrm{mm}$ mesh screens and then require a large amount of laboratory time for sorting and identification. Ground fish surveys, particularly those conducted using beam trawls, have already proved efficient for sampling and studying the functional components of the benthic megainvertebrate communities, from filter feeders to detritivores and scavengers (Brind'Amour et al., 2009; Kopp et al., 2013; Tillin et al., 2006). 
Despite the attractiveness of such "rapidly-collected" data, important issues regarding the accuracy of the species identification must be addressed before their widespread use. Ground fish surveys are mainly dedicated to fisheries, yet they are often limited by taxonomic and logistic constraints regarding zoobenthos identification. The survey coordinator has "parataxonomists" (sensu Gamez, 1991), rather than taxonomic experts, on board who can easily classify the macro- and megainvertebrate species into large recognizable taxonomic units or morphospecies (Oliver and Beattie, 1996), but hardly classify specimens to the species level. Morphospecies are defined as taxa distinguished solely on the basis of morphological differences easily identified by non-experts. This concept was used extensively in the mid-90s in the terrestrial realm (on plants and insects) and stimulated great debate at the time (Beattie and Oliver, 1999; Goldstein, 1999). However, as recently mentioned by Derraik et al. (2010), "morphospecies can be a useful technique for invertebrate studies, particularly where time and financial constraints exist [...]". From an ecological point of view, the concept of morphospecies embraces some fundamental aspects of functional ecology. Species sharing similar morphological traits form functional groups that likely occupy similar habitats or respond similarly to a stress (Keddy, 1992; Zobel, 1997). In the case of marine megainvertebrates sampled in bottom trawl surveys, morphospecies may thus define an ecological unit as being as relevant as species to study macro- and megabenthic communities.

Similar to the notion of morphospecies, is the concept of taxonomic sufficiency, which aims to identify organisms to the level of taxonomic resolution sufficient to satisfy the objectives of a particular study (Ellis, 1985; Terlizzi et al., 2003). It is commonly used in environmental assessment studies where taxa other than species serve to detect changes in assemblages exposed to anthropogenic stress (Ellis, 1985; Terlizzi et al., 2003) or natural conditions (Anderson et al., 2005; Vanderklift et al., 1998; Wlodarska-Kowalczuk and Kedra, 2007). 
The present study aims to quantify the loss of ecological information brought about by misidentification of the benthic macro- and megafauna in bottom trawl surveys. More specifically we (i) assess the loss of ecological information (taxa richness) with increasing taxonomic level and groups of morphospecies, (ii) compare the results among surveys conducted at different spatial scales (coastal bays to continental shelf), and (iii) provide a list of benthic invertebrate species, for which identification at the species level is crucial during bottom trawl surveys. Our study covers five different ecosystems sampled using different protocols (gear, time, area covered...), thereby precluding any direct comparison among these ecosystems. Our goal is thus not to compare the ecosystems with each other but rather to examine the results obtained in each system to verify the generalization of our conclusions.

\section{Materials and Methods}

\subsection{Case studies and sampling surveys}

The IBTSWG (International Bottom Trawl Surveys Working Group) is an ICES-

(International Council for the Exploration of the Sea) coordinated working group aiming to improve standardization and collaboration between a number of national surveys (Fig. 1). Two areas can be distinguished: (1) the North Sea and English Channel IBTS and (2) the Western and Southern area IBTS. These areas differ slightly in terms of sampling protocol (ICES, 2012). In the present study, we used the French dataset from three of the IBTS surveys: EVHOE (EValuation des ressources Halieutiques de l'Ouest Europe) for the Bay of Biscay, CGFS (Channel Ground Fish Survey) for the English Channel, and IBTS for the southern North Sea (Fig.1C, 1D \& 1E).

Simultaneously, France has carried out a number of dedicated coastal nursery surveys, mainly in estuaries, encompassing a variety of coastal habitats ranging from open shallow muddy estuarine areas, under the direct influence of freshwater inflows, to semi-enclosed sheltered muddy marsh areas with shellfish-farming, slightly affected by rivers (Gilliers et al., 2006). 
We used the datasets from two of these small-scale surveys: the Bay of Seine and the Bay of Vilaine (Fig. 1A \&1B). A technical description of the five sampling surveys is given in Table 1.

\subsection{Species taxonomy and selection}

Selection of the benthic megafauna in each case study was done prior to all analyses. We accounted for the selectivity of the sampling gear (GOV and beam trawl) and only taxa correctly identified at the species level and countable organisms were included in the analyses. Concurrently, we eliminated all pelagic species, clinging organisms such as barnacles, and species from the Cnidaria phylum from the datasets. Although these organisms represented a large proportion of species richness in two of the case studies $(\sim 38 \%$ in the Eastern English Channel basin and $\sim 26 \%$ in the southern North Sea), we found it very difficult to estimate their densities precisely. It is thus worth mentioning that any values of species richness given in the present study should be interpreted with caution as the complete range of benthic species was not included in the analyses. The goal of the study was not to compare the species richness among the ecosystems, but to estimate the loss of information within an ecosystem when lowering the taxonomic resolution. Nevertheless, the species remaining in the dataset after this selection are still representative of the megafauna found in each case study: between $62 \%$ and $89 \%$ of the species richness depending on the case study. Species taxonomy was retrieved and updated from the World Register of Marine Species (WoRMS, 2011).

Taxonomic sufficiency was evaluated at four taxonomic levels (species, genus, family and order) and for the morphospecies (morph) groupings. As morphospecies are morphologically, and often functionally, similar species we sometimes grouped species from different genera and/or families together (Supplementary Material A). For instance, the morphospecies "swimming crabs" (G19 in Supplementary Material A) included all the swimming crabs that 
look alike (e.g. Liocarcinus holsatus, Liocarcinus depurator, Polybius henslowii...). We estimated the differences between the morphospecies and the species level by calculating an error rate of identification using the formula from Derraik et al. (2010):

$$
\text { Identification error }=\frac{(N s-N m)}{N s}
$$

where $N_{s}$ is the number of species and $N_{m}$ the number of morphospecies (i.e. morph). This formula is one way of quantifying the loss of ecological information when species are identified at the morphospecies level.

Analyses were restricted to a single year for each case study as our objective was to compare the spatial community structure of the megabenthic invertebrate fauna without considering annual variability. The selected year was chosen as the most representative of the spatial structure for each case study after visual examination of the major habitats identified using the Hierarchical Cluster Analysis (HCA) described in the following section.

\subsection{Data analyses}

Data analyses were done in three steps. We first assessed the taxonomic community characteristics of the six case studies by calculating the species richness (SR, i.e. number of species) in each case study and by station, as well as a species to higher-level taxa ratio. According to Wlodarska-Kowalczuk and Kedra (2007), the latter ratio index can be viewed as a measure of the applicability of taxonomic sufficiency without making a specific test for it. High ratios could reach values of 4 to 6 whereas low ratios would be below 3 or 4 (Giangrande et al., 2005; Wlodarska-Kowalczuk and Kedra, 2007). Secondly, we conducted HCA with Ward's algorithm (Ward, 1963) on the sites*species densities (individual $\mathrm{m}^{-2}$ ) matrix of each case study to identify groups of stations (i.e. habitats) that were then used in the estimation of the taxonomic sufficiency. Results from the HCA were also compared with actual sedimentary and bathymetry strata in the five case studies. Thirdly, we assessed the 
similarity between the habitats within each case study by comparing the clusters obtained from the HCA for the 4 taxonomic levels and the morphospecies using the Adjusted Rand Index (ARI; Rand, 1971). The species level was considered as the "taxonomic reference" from which deviation was assessed. The ARI is commonly used in data clustering as a measure of the similarity between two partitions (for instance P1 and P2):

$$
\mathrm{ARI}=\frac{(n / 2)(a+d)-[(a+b)(\mathrm{a}+c)-(c+d)(b+d)]}{(n / 2)^{2}-[(a+b)(a+c)-(c+d)(b+d)]}
$$

where $n$ is the number of elements (here the number of stations) to be classified, $a$ and $b$ can be considered as the number of agreements between P1 and P2, whereas $c$ and $d$ are the number of disagreements between P1 and P2 (Table 2). P1 in our study was the result obtained from the species taxonomic level HCA, whereas P2 was the HCA result for the other taxonomic levels and morphospecies (i.e. genus, family, order and morph). A taxonomic level or morphospecies was deemed sufficient when the ARI at that taxonomic level or typology did not show great differences from the estimated ARI calculated at the species level (ARI = 70\%). We also conducted Non-metric Multidimensional Scaling (nMDS) on the Bray-Curtis dissimilarities using double square root- $(\sqrt{ } \sqrt{ })$ transformed matrices of taxonomic abundance data; and graphically represented the results using the HCA groups previously identified. These analyses were done for each taxonomic level and morphospecies (i.e. species, genus, family, order, and morph). The nMDS was conducted using two dimensions because the stress values for that number of dimensions were always below 0.05 , suggesting a good fit between the ordination and the Bray Curtis distances. The nMDS were done to assess and visualize the similarities and/or differences in community structure among the taxonomic levels and morphospecies. All the statistical analyses were conducted using R software (R Team, 2005) 


\section{Results}

\subsection{Species richness and habitat definition}

1. The five case studies used different sampling strategies and consequently displayed differences in their overall indices of community structure. They had different species numbers and average species richness but showed similarities in terms of species to higher-level taxa ratios (Table 3). As expected under the species-area relationship, surveys conducted in the two coastal bays (Bays of Seine and Vilaine) and the English Channel displayed a lower overall species richness (SR) than the broad-scale surveys carried out in the Bay of Biscay and North Sea. On average, the stations in the Bay of Seine and English Channel were poor in terms of species richness (average $\mathrm{SR}_{\text {stations }}=6.94$ and 6.49 , respectively) and displayed low and constant values of species to higher level taxa ratios, suggesting that these surveys are mainly characterized by a low number of non-redundant, closely related species. The Bay of Vilaine was characterized by relatively high average $\mathrm{SR}_{\text {stations }}$ values and a small coefficient of variation (ratio of the standard deviation to the mean) indicating a rich community with some evenness in SR distribution across the sampling stations. Low and constant values of species to taxa ratios were also observed, suggesting low taxonomic redundancy of species by genus, family and morphospecies. The two broad-scale surveys (i.e. Bay of Biscay and North Sea) generally displayed richer communities, with 130 and 111 species, respectively, and high average $\mathrm{SR}_{\text {stations }}$ values, indicating 
that these large-scale ecosystems encompass a large diversity of habitats, themselves composed of a large number of species. Just as for the other three surveys, the low and constant values of ratios of species to higher-level taxa observed in the Bay of Biscay and North Sea surveys (from 1.00 to 3.33) suggest a low number of related species.

All the habitats defined by HCA analyses in each case study generally corresponded to bathysedimentary strata (Fig. $1 \&$ Table 4 ). The limits of each habitat were defined by grouping the stations corresponding roughly to HCA results. A full environmental description of the different habitats in each case study is given in Table 4 with references to the associated literature, but here we focus only on the main results. We defined three to four habitats in the two coastal bays and in the large-scale ecosystems (Table 4). All habitats described in each of the case studies were then used as a grouping variable in the analyses of the taxonomic sufficiency.

\subsection{Analyses of morphospecies}

The taxa richness computed using the morphospecies datasets gave similar results to those estimated using the species dataset: an increasing gradient of morphospecies richness in the following order: Bay of Seine, Bay of Vilaine, English Channel, Bay of Biscay and North Sea surveys. We then compared the morphospecies (morph) with the species identification by calculating an identification error rate; this ranged between $12.07 \%$ (in the Bay of Vilaine) and $18.75 \%$ (in the Bay of Seine) for the small-scale surveys. The large-scale fish surveys, such as those ones conducted in the Bay of Biscay and the North Sea, displayed error rates of 18.46 and $17.91 \%$, respectively. Over the 47 morphospecies identified by the experts, $62 \%$ included multiple genera and $36 \%$ were composed of multiple families. Among these families, we specifically recognized 23 that included several morphospecies (morph, Table 5 
\& Supplementary Material A) that determine the benthic community structure of the five case studies.

\subsection{Rand index and cluster comparisons: status of the benthic community}

A general decrease in the ARI was observed for the five case studies as we moved away from the taxonomic reference (i.e. species level) towards the order level (Fig. 2). The morphospecies displayed correlation values close to those for the family and genus levels. Similar results were underlined by the nMDS ordinations, where a change in site distribution was observed at the order level. This result was observed in all the case studies, thus only the ordinations for the English Channel are presented (Fig. 3). The ordinations for the five case studies and for all the groupings are given in Supplementary Material B.

The highest similarities in the ordinations and in the ARI were found for the two coastal bays, where values never went below the 0.80 threshold (except for the order level). The lowest ARI was observed in the Bay of Biscay and North Sea ecosystems, where the values were never higher than 0.70 . The English Channel followed the general pattern: decreasing values from species to order level but with ARI values ranging between the small- and large-scale case studies.

\section{Discussion}

\subsection{Different ecosystems and spatial scales, similar responses}

The five surveys were conducted at different spatial scales and showed differences in terms of habitat and community structure. As expected from the species-area relationships, the smallscale beam trawl surveys displayed lower species richness than the large-scale bottom trawl surveys (see Supplementary Material A for a species list from each case study). However, the five surveys displayed low and constant species to higher-taxa-level ratios (around 1.5) suggesting low species redundancy with increasing taxonomic level (for genus and family) in all the studied ecosystems. Furthermore, species richness in the five ecosystems was strongly 
correlated with richness at other taxa levels (i.e. genus, family, and morphospecies), indicating that regardless of the scale of the survey and/or the taxonomic level used, the overall richness of the site was maintained. Concurrently, the general pattern of the ARI shared by the five surveys suggested that family-level and morphospecies groups are of sufficient morphological or functional dissimilarity to discriminate the different habitats in each of the survey areas. This finding is in agreement with Bacci et al. (2009), who compared taxonomic sufficiency approach in two contrasted case studies (shelf vs. estuarine Mediterranean ecosystems). They concluded that taxonomic sufficiency appears to be a valid instrument to analyse and describe the structure of benthic communities in the two ecosystems they studied and in cases of taxonomically complex communities. These findings also agree with those of other studies looking at the impact of using lower taxonomic levels in marine biodiversity assessment (Anderson et al., 2005; Gaston, 2000; Giangrande et al., 2005; Olsgard et al., 2003).

Although similar patterns in taxonomic sufficiency were observed among our case studies, differences in the absolute values of ARI were also visible. This suggests that lowering the taxonomic level in systems dominated by few families or orders and displaying low species richness will have less impact (in terms of correlation with the species level) than doing this in species-rich systems displaying high evenness across several families (Bowman and Bailey, 1997; Heino, 2008). In the five ecosystems studied, this pattern was particularly apparent where similar patterns of ARI and species to taxa ratios were observed, but where a quantitative loss of information (lower ARI values) was also noticeable from small-scale to large-scale surveys. Hawkins and Norris (2000) and Heino (2008) suggested that the relationship between species richness and the loss of information at low taxonomic resolution may be partly due to adaptive radiation in species taxa. Species in family-rich taxa would have a broader range of different ecological niches, displaying different responses to the 
environment. Therefore, the loss of the species level in the assessment of such ecosystems such ecosystems would likely lead to significant functional erosion.

The five case studies differ not only in their community structures but also in the range of habitats they cover and in their sampling protocol (type of bottom trawl, area swept...). The two small-scale systems (Bay of Seine and Bay of Vilaine) are both composed of a limited number of sandy and muddy habitats in a similar range of depths, whereas the other three systems all cover a large latitudinal range displaying a broad gradient of environmental conditions (sediments, depth, salinity, see Table 4). Species in environment-rich systems will likely occupy a wider range of ecological niches than species inhabiting systems with less environmental heterogeneity (Baldi, 2008; Connor and McCoy, 1979), which might explain the decreasing gradient of taxonomic sufficiency as we move from "species-poor" ecosystems towards "species-rich" ones. It is worth mentioning that although the ARI values decrease in these large ecosystems, the range of absolute values is still highly satisfactory and comparable to other studies (Bevilacqua et al., 2009; Soares-Gomes et al., 2012; Wlodarska-Kowalczuk and Kedra, 2007).

\subsection{The morphospecies: a functional concept}

Habitat template theory proposes that species with similar morphological traits occupy similar habitats (Southwood, 1977). According to this hypothesis, habitat is the setting where evolution occurs, giving specific life history strategies to organisms thereby grouping similar functional attributes in similar habitats. This concept is closely related to the morphospecies and one could argue that grouping species according to their morphological similarities, as is done with morphospecies, is an indirect way of including functional aspects of the community in the analyses.

The use of morphospecies such as the one in the present study is quite widespread in the terrestrial realm (Derraik et al., 2010; Oliver and Beattie, 1996; Pik et al., 1999), remote 
ecosystems (Barnes et al., 2009; Sabbatini et al., 2002) and estuaries (Soares-Gomes et al., 2012). For instance, morphospecies are used as Operational Taxonomic Units (OTU) in highresolution seabed imagery or deep-sea areas where identification is often impractical and unreliable (Barnes et al., 2009), or when dealing with taxonomically difficult groups of rare and small species such as micro-gastropods (Albano et al., 2011). In these previous studies, the morphospecies were considered in the same way as they were in our study, i.e. as a unique group of (most likely) several species displaying sufficient morphological similarities to be classified together. Here, morphospecies were identified by experts, based on the similarity of their major morphological characteristics as well as the similarity in their functional attributes (Bremner, 2008; Bremner et al., 2003; Tillin et al., 2006).

Results from the ARI analyses coupled with the experts' identification of the morphospecies in each of the five case studies allowed an important practical issue to be addressed: the creation of a list of families and species for which adequate efforts of identification should be made on board (Table 5). The species included in this list are those that are structural for the benthic communities of the surveys; the morphological similarities they display thereby indicate similar underlying functional traits.

We deliberately excluded uncountable and clinging organisms from our analyses. These organisms are often viewed as problematic because they are difficult to assess quantitatively (Zettler et al., 2007). This is however a strong limitation of benthic studies, as these organisms may be structurally important species in some ecosystems (e.g. English Channel and North Sea). There is thus a need to develop statistical techniques or methods to jointly process these organisms along with the countable ones. Such parameters allow an integrated view of the macro and megabenthic communities of the marine realm, which is required to improve our knowledge of these communities. 


\subsection{Implications for the MSFD}

In the MSFD, each Member State had to undertake an Initial Assessment of the current ecological state by the end of 2012, and identify existing data that could be useful for the Initial Assessment and development of the indicators. Some Member States have already started to assess the environmental status of their marine waters (Borja et al., 2011) while others are still compiling the data to inform the various descriptors (Rombouts et al., 2013). Nevertheless, several indicators are still being developed and tested and are thus far from being operational and directly implemented in the MSFD (Rombouts et al., 2013). For instance, indicators from the Sea Floor Integrity descriptor (e.g. D6) require ecological knowledge on data-poor habitats such as the offshore and deep-sea benthic communities (Rice et al., 2012). These remote ecosystems represent large surfaces, and discrepancies are expected between the large geographic areas covered by these surfaces in the various subregions and the sampling gear traditionally used in benthic ecology (i.e. grabs). According to (Rice et al., 2010), “other strategy must be developed for general assessments of environmental status of sea floor integrity on regional and sea-wide scales." Fisheries science bottom trawl surveys cover very broad geographic areas. For instance the surface of the study areas of the IBTS (in the North Sea) and EVHOE (in the Bay of Biscay) surveys are about 11 $112 \mathrm{~km}^{2}$ and $150000 \mathrm{~km}^{2}$ respectively, thereby encompassing a large number of habitats and indeed benthic communities. We showed that the data collected in these large-scale and other small-scale bottom trawl fisheries surveys could correctly identify benthic habitats previously described by other studies that used grab samples (Table 4). These findings underline that data obtained from fisheries surveys may well complement those from grab samples to provide useful information for MSFD benthic descriptors (e.g. D6: Sea Floor Integrity). The use of morphospecies or lower taxonomic levels, such as genus or family, could thus be used to homogenize the combined datasets. This was notably done by Dimitriou et al (2012) 
in a recent meta-analysis conducted on a large database of macrofaunal samples compiled by assembling various data sets from the Eastern Mediterranean including sublittoral and continental shelf surveys of various types. Their final dataset inevitably comprised taxa identified at different taxonomic levels. They suggested a benthic index that could be calculated using the family level (Benthic Quality Index, BQI) and showed that this strongly agreed with the existing Water Framework Directive (WFD) indicators. In the same way, Munari et al. (2009) calculated four benthic indices to assess the water quality of the Adriatic coastal transitional ecosystems to eventually implement the WFD and concluded that " $A$ genus or family level of identification for the WFD implementation in the benthic compartment of Italian transitional waters might be sufficient for evaluating the status of such water bodies".

The two aforementioned studies were conducted in the context of the WFD. However, as recently underlined by Borja et al. (2010), the MSFD provides a more holistic and functional approach than the WFD as it breaks down the ecosystems into a set of process-like components (i.e. functional descriptors) and recombines them in an integrated approach (the GES assessment). For instance, indicator 6.2.2 from the D6 addresses the condition of benthic communities using multi-metric indices such as species diversity and richness, or the ratio of opportunistic to sensitive species. We argue that this indicator could be well informed using the morphospecies identified in our study as morphological and anatomical attributes constrain the role a species may play in the community, and species sharing similar attributes form functional groups are likely to occupy similar habitats and respond similarly to anthropogenic pressures (Bremner, 2008; Tonn et al., 1990). Classification of species according to a suite of biological or morphological traits (i.e. Biological Traits Analysis, BTA) has been used to reflect the changes in the system functioning (Bremner, 2008). We therefore suggest that whenever it is impossible to identify taxa at the species level, BTA 
could be compiled on a mixed species and morphospecies trait matrix without losing any functional information (Bremner et al., 2003).

\section{Conclusions}

Species is the basic ecological unit in the ecological niche and succession theories; whilst identification at the species level is always preferred over any other taxonomic levels. Nevertheless, aggregation of species to higher taxonomic levels may sometimes be unavoidable, as we know or suspect that errors of identification occur in some surveys. In such cases, aggregation should be undertaken with caution, as the taxonomic sufficiency may be highly dependent on the community structure of the system under study (Giangrande et al., 2005), although this may also not be the case (Bacci et al., 2009). Furthermore, the use of any higher taxonomic level in species-rich ecosystems will inevitably and unfortunately lead to lower diversity estimations. This study has indicated that, although absolute values of diversity can be lowered, the general spatial patterns distinguishing benthic communities are still maintained. We confirm the conclusions reached in several other studies (Dethier and Schoch, 2006; Guzman-Alvis and Carrasco, 2005; Somerfield and Clarke, 1995; Terlizzi et al., 2008; Vanderklift et al., 1998; Wlodarska-Kowalczuk and Kedra, 2007), indicating that genus and family levels are generally good surrogates for species in benthic community analyses. We underline that analyses of morphospecies may be better suited than genus or family level analyses because morphospecies classification only increases the taxonomic level of a certain number of species, i.e. the misidentified ones, thereby keeping most of the ecological information for the rest of the community "intact". Nevertheless, the morphospecies classification offers no panaceas, only new and reliable solutions to counter the problem of misidentification that sometimes occurs on board fisheries science bottom trawl surveys. 
From an applied perspective, this study suggests that bottom trawl survey data can be used as a reliable and complementary source of data to dedicated macrobenthos surveys (e.g. grab data), to provide information for MSFD benthic descriptors (D6 and, to a lesser extent, D1, D2, D4). The use of such complementary sources of data will likely require the combination and standardization of the various databases, which might be composed of several surveys using different gears, sampling strategies, and taxonomic levels of identification.

Morphospecies could thus be an appropriate substitute in this context.

\section{Acknowledgments}

This study was partly supported by the EU FP7 project BENTHIS; the French research agency (ANR), through the project COMANCHE; and by the GIP Seine Aval, through the project COLMATAGE. The authors are grateful to all the scientists and crews who participated in the NOURSEINE, NURSE, EVHOE, CGFS, and IBTS bottom trawl surveys. The authors would also especially like to thank Jocelyne Martin for the species identification of the NURSE, CGFS, IBTS and EVHOE surveys. They also acknowledge an anonymous reviewer that greatly enhanced the manuscript.

\section{References}

Albano, P.G., Sabelli, B., Bouchet, P., 2011. The challenge of small and rare species in marine biodiversity surveys: microgastropod diversity in a complex tropical coastal environment. Biodiversity \& Conservation 20, 3223-3237.

Anderson, M.J., Connell, S.D., Gillanders, B.M., Diebel, C.E., Blom, W.M., Saunders, J.E., Landers, T.J., 2005. Relationships between taxonomic resolution and spatial scales of multivariate variation. Journal of Animal Ecology 74, 636-646.

Bacci, T., Trabucco, B., Marzialetti, S., Marusso, V., Lomiri, S., Vani, D., Virno Lamberti C., 2009. Taxonomic sufficiency in two case studies: where does it work better? Marine Ecology 30, 13-19.

Baldi, A., 2008. Habitat heterogeneity overrides the species-area relationship. Journal of Biogeography 35, 675-681.

Barnes, D.K.A., Kaiser, S., Griffiths, H.J., Linse, K., 2009. Marine, intertidal, freshwater and terrestrial biodiversity of an isolated polar archipelago. Journal of Biogeography 36, 756-769.

Beattie, A.J., Oliver, I., 1999. Biodiversity buzzwords: another reply to Goldstein. Conservation Biology 13, 1514. 
Bevilacqua, S., Fraschetti, S., Terlizzi, A., Boero, F., 2009. The use of taxonomic distinctness indices in assessing patterns of biodiversity in modular organisms. Marine Ecology 30, 151-163.

Borja, A., Elliott, M., Carstensen, J., Heiskanen, A.-S., van de Bund, W., 2010. Marine management - Towards an integrated implementation of the European Marine Strategy Framework Directive and the Water Framework Directive. Marine Pollution Bulletin 60, 2175-2186.

Borja, A., Galparsoro, I., Irigoien, X., Iriondo, A., Menchaca, I., Muxika, I., Pascual, M., Quincoces, I., Revilla, M., Germán Rodríguez, J., Santurtún, M., Solaun, O., Uriarte, A., Valencia, V., Zorita, I., 2011. Implementation of the European Marine Strategy Framework Directive: a methodological approach for the assessment of environmental status, from the Basque Country (Bay of Biscay). Marine Pollution Bulletin 62, 889904.

Bowman, M.F., Bailey, R.C., 1997. Does taxonomic resolution affect the multivariate description of the structure of freshwater macroinvertebrate communities. Canadian Journal of Fisheries ad Aquatic Sciences 54, 1802-1807.

Bremner, J., 2008. Species' traits and ecological functioning in marine conservation and management. Journal of Experimental Marine Biology and Ecology 366, 37-47.

Bremner, J., Rogers, S.I., Frid, C.L.J., 2003. Assessing functional diversity in marine benthic ecosystems: a comparison of approaches. Marine Ecology Progress Series 254, 11-25.

Brind'Amour, A., Rouyer, A., Martin, J., 2009. Functional gains of including non-commercial epibenthic taxa in coastal beam trawl surveys: a Note. Continental Shelf Research 29, 1189-1194.

Cabioch, L., 1968. Contribution à la connaissance des peuplements benthiques de la Manche occidentale. Thesis published in Cahiers de biologie marine, tome IX, cahier 5 suppl. $724 \mathrm{pp}$.

Connor, E.F., McCoy, E.D., 1979. The Statistics and Biology of the Species-Area Relationship. American Naturalist 113, 791-833.

Dauvin, J.C., Desroy, N., Janson, A.L., Vallet, C., Duhamel, S., 2006. Recent changes of estuarine benthic and suprabenthic communities in response to harbour infrastructural development. Marine Pollution Bulletin 55, 80-90.

Desroy, N., Janson, A.L., Denis, L., Charrier, G., Lesourd, S., Dauvin, J.C., 2007. The Intraannual variability of soft bottom macrobenthos abundance patterns in the North Channel of the Seine Estuary. Hydrobiologia 588 173-188.

Derraik, J.G.B., Early, J.W., Closs, G.P., Dickinson, K.J.M., 2010. Morphospecies and taxonomic species comparison for Hymenoptera. Journal of Insect Science 10, 1-7.

Dethier, M.N., Schoch, G.C., 2006. Taxonomic sufficiency in distinguishing natural spatial patterns on an estuarine shoreline. Marine Ecology Progress series 306, 41-49.

Dimitriou, P.D., Apostolaki, E.T., Papageorgiou, N., Reizopoulou, S. Simboura, N., Arvanitidis, C., Karakassis, I., 2012. Meta-analysis of a large data set with Water Framework Directive indicators and calibration of a Benthic Quality Index at the family level. Ecological Indicators 20, 101-107.

Elkaim, B., Ibanez, F., Proniewski, F., 1982. Le benthos subtidal de l'estuaire de la Seine: Analyse statistique des peuplements. Journal of Experimental Marine Biology and Ecology 64, 231-252. 
Ellis, D., 1985. Taxonomic sufficiency in pollution assessment. Marine Pollution Bulletin 16, 459.

European Commission. 2008. Directive 2008/56/EC of the European Parliament and of the Council of 17 June 2008 establishing a framework for community action in the field of marine environmental policy (Marine Strategy Framework Directive).

European Commission, 2010. Commission Decision of 1 September 2010 on criteria and methodological standards on good environmental status of marine waters (notified under document C(2010) 5956)(2010/477/EU). Official Journal of the European Union, L232: 12-24.

Foveau, A., 2009. Habitats et communautés benthiques du bassin oriental de la Manche : état des lieux au début du XXIème siècle. PhD Thesis. 308 pp.

Gamez, R., 1991. Biodiversity conservation through facilitation of its sustainable use: Costa Rica's National Biodiversity Institute. Trends in Ecology \& Evolution 6, 377-378.

Gaston, K. J., Blackburn, T. M., 1995. Mapping biodiversity using surrogates for species richness: macro-scales and New World birds. Proceedings of the Royal Society of London. Series B. 262, 335-341.

Giangrande, A., Licciano, M., Musco, L. 2005. Polychaetes as environmental indicators revisited. Marine Pollution Bulletin 50, 1153-1162.

Gilliers, C., Le Pape, O., Desaunay, Y., Morin, J., Guérault, D., Amara, R., 2006. Are growth and density quantitative indicators of essential fish habitat quality? An application to the common sole Solea solea nursery grounds. Estuarine Coastal and Shelf Science 69, 96-106.

Goldstein, P.Z., 1999. Functional ecosystems and biodiversity buzzwords. Conservation Biology 13, 247-255.

Guzman-Alvis, A.I., Carrasco, F., 2005. Taxonomic aggregation and redundancy in a tropical macroinfaunal assemblage of the southern Caribbean in the detection of temporal patterns. Scientia Marina 69, 133-141.

Hawkins, C.P., Norris, R.H., 2000. Effects of taxonomic resolution and use of subsets of the fauna on the performance of RIVPACS-type models. In: Wright, J.F., Sutcliffe, D.W. \& Furse, M.T. (eds) Assessing the biological quality of freshwaters: RIVPACS and similar techniques, Freshwater Biological Association, Ambleside.

Heino, J., 2008. Influence of taxonomic resolution and data transformation on biotic matrix concordance and assemblage-environment relationships in stream macroinvertebrates. Boreal Environmental Research 13, 359-369.

ICES, 2012. International Council for the Exploration of the Sea. Visited 13/11/2012. http://datras.ices.dk/Home/Descriptions.aspx\#IBTS.

Keddy, P.A., 1992. Assembly and response rules: two goals for predictive community ecology. Journal of Vegetation Science 3, 157-164.

Kopp, D., Le Bris, H., Grimaud, L., Nerot, C., Brind'Amour, A., 2013. Spatial analysis of the trophic interactions between two juvenile fish species and their preys along a coastalestuarine gradient. Journal of Sea Research 81: 40-48.

Laffargue, P., Martin, J., 2010. On the relevance of epibenthic invertebrate community data from standard fishery trawling surveys to qualify soft bottom habitats. In. Proc ICES Annual Science Conference, Nantes, France 
Le Bris, H., Glémarec, M., 1995. Macrozoobenthic communities of an oxygen undersaturated coastal ecosystem : the Bay of Vilaine (Southern Britany) Oceanologica acta $18,573-581$.

Munari, C., Manini, E., Pusceddu, A., Danovaro, R., Mistri, M., 2009. Response of BITS (a benthic index based on taxonomic sufficiency) to water and sedimentary variables and comparison with other indices in three Adriatic lagoons. Marine Ecology 30, 255-268.

Oliver, I., Beattie, A.J., 1996. Invertebrate morphospecies as surrogates for species: A case study. Conservation Biology 10, 99-109.

Olsgard, F., Brattegard, T., Holthe, T., 2003. Polychaetes as surrogates for marine biodiversity: lower taxonomic resolution and indicator groups. Biodiversity and Conservation 12, 1033-1049.

Pik, A.J.P., Oliver, I., Beattie, A.J., 1999. Taxonomic sufficiency in ecological studies of terrestrial invertebrates. Australian Journal of Ecology 24, 555-562.

R Team, 2005. R: A language and environment for statistical computing, R Foundation for Statistical Computing, ISBN 3-900051-00-3 ed, Vienna, Austria

Rand, W.M., 1971. Objective Criteria for the Evaluation of Clustering Methods. Journal of the American Statistical Association 66, 846-850.

Rice, J., Arvanitidis, C., Borja, A., Frid, C., Hiddink, J., Krause, J., Lorance, P., Ragnarsson, S.A., Skold, M., Trabucco, B., 2010. Marine Strategy Framework Directive - Task Group 6 Report Seafloor integrity, in: Joint Research Centre, L.O.f.O.P.o.t.E.C. (Ed.), Luxembourg, p. 73 pp.

Rice, J., Arvanitidis, C., Borja, A., Frid, C., Hiddink, J., Krause, J., Lorance, P., Ragnarsson, S.A., Skold, M., Trabucco, B., Enserink, L., Norkko, A., 2012. Indicators for SeaFloor Integrity under the European Marine Strategy Framework Directive. Ecological Indicators 12, 174-184.

Rombouts, I., Beaugrand, G., Fizzala, X., Gaill, F., Greenstreet, S.P.R., Lamare, S., Le Loc'h, F., McQuatters-Gollop, A., Mialet, B., Niquil, N., Percelay, J., Renaud, F., Rossberg, A.G., Feral, J.P., 2013. Food web indicators under the Marine Strategy Framework Directive : from complexity to simplicity ? Ecological Indicators 29, 246-254.

Sabbatini, A., Morigi, C., Negri, A., Gooday, A. J., 2002. Soft-shelled benthic Foraminifera from a hadal site $(7800 \mathrm{~m}$ water depth) in the Atacama Trench (SE Pacific): preliminary observations. Journal of Micropaleontology 21, 131-135.

Sanvicente-Anorve L., Leprêtre A., Davoult D., 2002. Spatial variations of the diversity and the quantitative structure of the benthic communities in the eastern English Channel. Biodivers. Conserv. 11: 265-282.

Soares-Gomes A., Mendes, C.L.T, Tavares, M., Santi, L., 2012. Taxonomic sufficiency of polychaete taxocenes for estuary monitoring. Ecological Indicators 15, 149-156.

Somerfield, P.J., Clarke, K.R., 1995. Taxonomic levels, in marine community studies, revisited. Marine Ecology Progress series 127, 113-119.

Southwood, T.R.E., 1977. Habitat, the templet for ecological strategies. Journal of Animal Ecology 46, 337-365.

Team, R.D.C., 2005. R: A language and environment for statistical computing, R Foundation for Statistical Computing, ISBN 3-900051-00-3 ed, Vienna, Austria

Terlizzi, A., Anderson, M.J., Bevilacqua, S., Fraschetti, S., Włodarska-Kowalczuk, M., Ellingsen, K.E., 2008. Beta diversity and taxonomic sufficiency: do higher-level taxa reflect heterogeneity in species composition. Diversity and Distributions 15, 450-458. 
Terlizzi, A., Bevilacqua, S., Fraschetti, S., Boero, F., 2003. Taxonomic sufficiency and the increasing insufficiency of taxonomic expertise. Marine Pollution Bulletin 46, 556561.

Tillin, H.M., Hiddink, J.G., Jennings, S., Kaiser, M.J., 2006. Chronic bottom trawling alters the functional composition of benthic invertebrate communities on a sea-basin scale. Marine Ecology Progress series 318, 31-45.

Tonn, W.M., Magnuson, J.J., Rask, M., Toivonen, J., 1990. Intercontinental comparison of small-lake fish assemblages: the balance between local and regional processes. The American Naturalist 136, 345-375.

Vanderklift, M.A., Ward, T.J., Phillips, J.C., 1998. Use of assemblage derived from different taxonomic levels to select areas for conserving marine biodiversity. Biological Conservation 86, 307-315.

Vaz, S., ter Hofstede, R., Martin, J., Dewarumez, J.-M., Verin, Y., Le Roy, D., Heessen, H., Daan, N., 2007. Benthic invertebrates community structure inferred from bottom trawl hauls observations and its relationships to abiotic conditions in the southern North Sea. ICES CM 2007/A:03, ICES Annual Science Conference, Helsinki, Finland.

Ward, J.H. (1963). Hierarchical Grouping to optimize an objective function. Journal of American Statistical Association, 58(301), 236-244.

Wlodarska-Kowalczuk, M., Kedra, M., 2007. Surrogacy in natural patterns of benthic distribution and diversity: selected taxa versus lower taxonomic resolution. Marine Ecology Progress series 351, 53-63.

WoRMS (2011). Accessed through: World Register of Marine Species at http://www.marinespecies.org/aphia.php? $\mathrm{p}=$ taxdetails\&id=100808 on 2011-10-24

Zettler, M.L., Schiedek, D., Bobertz, B. 2007. Benthic biodiversity indices versus salinity gradient in the southern Baltic Sea. Marine Pollution Bulletin 55, 268-270.

Zobel, M., 1997. The relative role of species pools in determining plant species richness: an alternative explanation of species coexistence? Trends in Ecology and Evolution 12, 266-269. 
Figure captions

Fig. 1. Map of geographic areas and sampling stations for each of the five French datasets: Bay of Seine (A), Bay of Vilaine (B), Eastern English Channel basin (C), Bay of Biscay (D), North Sea (E). The dotted lines delineate the habitats found in the present study using cluster analyses (see Materials and Methods for details). The habitats described here (H1 to H4) are a schematic view of the macro- and megabenthic communities in the studied ecosystems. These are described in detail for each ecosystem in Table 4.

Fig. 2. Adjusted Rand Index (ARI) values calculated for the five case studies. ARI is a measure of similarity between a taxonomic reference (here the species level) and another taxonomic level. It varies between 0 and 1 (see the Materials and Methods section for more details).

Fig. 3. NMDS ordination on Bray-Curtis similarities using $\sqrt{ } \sqrt{ } x$-transformed taxonomic densities for the English Channel. The legends correspond to the number of predefined habitats in each case study. Ordinations of all the case studies can be found in the figures included in Supplementary Material B. 
Table 1 Technical description of the sampling surveys used in the five case studies.

\begin{tabular}{|c|c|c|c|c|c|}
\hline Location & Bay of Seine & $\begin{array}{l}\text { Bay of } \\
\text { Vilaine }\end{array}$ & $\begin{array}{l}\text { English } \\
\text { Channel }\end{array}$ & $\begin{array}{l}\text { Bay of } \\
\text { Biscay }\end{array}$ & North Sea \\
\hline Year & 2008 & 2009 & 2007 & 2009 & 2011 \\
\hline $\begin{array}{l}\text { Depth range } \\
\text { (m) }\end{array}$ & $5-20$ & $5-35$ & $5-100$ & $30-600$ & $15-200$ \\
\hline Gear name & $\begin{array}{l}3 \mathrm{~m} \text { beam } \\
\text { trawl }\end{array}$ & $\begin{array}{l}3 \text { m beam } \\
\text { trawl }\end{array}$ & $\begin{array}{l}19.70 / 25.90 \\
\text { GOV }\end{array}$ & $36 / 47 \mathrm{GOV}$ & $36 / 47 \mathrm{GOV}$ \\
\hline $\begin{array}{l}\text { Vertical } \\
\text { opening (m) }\end{array}$ & 0.5 & 0.5 & 3 & 4 & \\
\hline $\begin{array}{l}\text { Cod size } \\
(\mathrm{mm})\end{array}$ & 20 & 20 & 20 & & 20 \\
\hline $\begin{array}{l}\text { Trawl } \\
\text { duration } \\
(\min )\end{array}$ & 15 & 15 & 30 & 30 & 30 \\
\hline $\begin{array}{l}\text { Surface } \\
\text { covered }\left(\mathrm{m}^{2}\right)\end{array}$ & $\sim 4500$ & $\sim 4500$ & & $\sim 69000$ & $\sim 35000$ \\
\hline
\end{tabular}


Table 2 Match and mismatch matrix used in the calculation of the adjusted Rand Index (ARI). $a, b, c$, and, $d$ are counts of unique pairs.

\begin{tabular}{|c|c|c|c|c|}
\hline \multirow{5}{*}{ 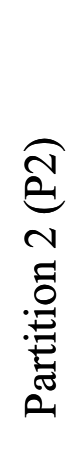 } & \multicolumn{4}{|c|}{ Partition 1 (P1) } \\
\hline & Number of pairs & Same cluster & Different clusters & Sums \\
\hline & Same cluster & $a$ & $b$ & $a+b$ \\
\hline & Different clusters & $c$ & $d$ & $c+d$ \\
\hline & Sums & $a+c$ & $b+d$ & \\
\hline
\end{tabular}


Table 3 Summary of the number of stations included in the analyses for each case study and the indices for community structure: total species richness (SR), average SR by sampling sites, and average species to higher-level taxa ratios (Ratio). Standard deviations given are in parenthesis.

\begin{tabular}{|c|c|c|c|c|c|}
\hline Case study & Bay of Seine & $\begin{array}{l}\text { Bay of } \\
\text { Vilaine }\end{array}$ & $\begin{array}{l}\text { English } \\
\text { Channel }\end{array}$ & Bay of Biscay & North Sea \\
\hline $\begin{array}{l}\text { Number of } \\
\text { stations }\end{array}$ & 46 & 49 & 92 & 62 & 88 \\
\hline SR & 32 & 58 & 58 & 130 & 111 \\
\hline Average & $6.94(2.10)$ & $13.76(3.15)$ & $6.49(3.21)$ & $19.50(6.34)$ & $11.23(6.49)$ \\
\hline \multicolumn{6}{|l|}{$\mathrm{SR}_{\text {stations }}$} \\
\hline Ratio Sp/Gen & 1.143 & 1.123 & 1.158 & 1.095 & 1.437 \\
\hline Ratio Sp/Fam & 1.209 & 1.323 & 1.365 & 1.453 & 1.640 \\
\hline Ratio Sp/Ord & 2.201 & 2.157 & 2.442 & 2.628 & 3.330 \\
\hline Ratio & 1.143 & 1.313 & 1.245 & 1.271 & 1.537 \\
\hline $\mathrm{Sp} / \mathrm{morph}$ & & & & & \\
\hline
\end{tabular}


Table 4 Environmental and biological description of the different habitats observed in each case study. These habitats were generally associated with the bathysedimentary gradient, as identified in previous studies (Cabioch, 1968; Dauvin et al., 2006; Desroy et al., 2007; Elkaim et al. 1982; Foveau, 2009; Kopp et al., 2013; Laffargue and Martin, 2010; Le Bris and Glemarec, 1995; Sanvicente-Anorve et al., 2002; Vaz et al., 2007) and corresponded to the predefined groups used in the nMDS analyses.

\begin{tabular}{|c|c|c|c|c|c|}
\hline Habitat & Bay of Seine & Bay of Vilaine & $\begin{array}{l}\text { English } \\
\text { Channel }\end{array}$ & Bay of Biscay & North Sea \\
\hline$H 1$ & $\begin{array}{l}\text { Muddy } \\
\text { estuarine } \\
\text { habitat under } \\
\text { high river } \\
\text { discharge } \\
\text { influence. } \\
\text { Benthic } \\
\text { assemblage } \\
\text { characterized } \\
\text { by Pectinaria, } \\
\text { Cerastoderma, } \\
\text { and Nepthys. }\end{array}$ & $\begin{array}{l}\text { Muddy } \\
\text { habitat } \\
\text { ranging } \\
\text { between } 0 \text { to } \\
5 \mathrm{~m} \text { under } \\
\text { river } \\
\text { discharge } \\
\text { influence. } \\
\text { Benthic } \\
\text { assemblage } \\
\text { dominated by } \\
\text { Cerastoderma } \\
\text { edule. }\end{array}$ & $\begin{array}{l}\text { Shallow } \\
\text { coastal } \\
\text { habitat where } \\
\text { fine sand and } \\
\text { mud } \\
\text { constitute the } \\
\text { bulk of the } \\
\text { sediment, } \\
\text { characterized } \\
\text { by the deposit } \\
\text { feeder Abra } \\
\text { alba and } \\
\text { Nepthys } \\
\text { cirrosa. }\end{array}$ & $\begin{array}{l}\text { Mixed sandy and } \\
\text { muddy habitats } \\
\text { ranging } 150-350 \\
\text { m extending from } \\
\text { the mid-shelf to } \\
\text { shelf break, } \\
\text { characterized by } \\
\text { e.g. Hyalinoecia } \\
\text { tubicola, } \\
\text { Leptometra celtica, } \\
\text { Pagurus prideaux, } \\
\text { Adamsia } \\
\text { carciniopados }\end{array}$ & $\begin{array}{l}\text { Muddy and } \\
\text { warm water } \\
\text { habitat ranging } \\
30-50 \mathrm{~m} \\
\text { depth, } \\
\text { characterized } \\
\text { by Liocarcinus } \\
\text { depurator, } \\
\text { Paguridae and } \\
\text { Pandalus. }\end{array}$ \\
\hline$H 2$ & $\begin{array}{l}\text { Muddy and } \\
\text { sandy } \\
\text { euryhaline } \\
\text { habitat. Benthic } \\
\text { assemblage, } \\
\text { characterized } \\
\text { by Owenia, } \\
\text { Lanice, and } \\
\text { Eteone. }\end{array}$ & $\begin{array}{l}\text { Muddy and } \\
\text { sandy habitat } \\
\text { ranging 5-10 } \\
\text { m under river } \\
\text { discharge } \\
\text { influence in } \\
\text { wet winters. } \\
\text { Benthic } \\
\text { assemblage } \\
\text { dominated by } \\
\text { Owenia } \\
\text { fusiformis. }\end{array}$ & $\begin{array}{l}\text { Sandbanks in } \\
\text { fine to coarse } \\
\text { grains and } \\
\text { shallow } \\
(10-30 \mathrm{~m}) \\
\text { habitat } \\
\text { dominated by } \\
\text { Ophelia } \\
\text { borealis, } \\
\text { Nereis } \\
\text { cirrosa, and } \\
\text { Spiophanes } \\
\text { bombyx. }\end{array}$ & $\begin{array}{l}\text { Deep muddy } \\
\text { grounds at } \\
\text { the shelf } \\
\text { slope around } \\
500 \text { m deep, } \\
\text { characterized } \\
\text { by } \\
\text { Pasiphaea } \\
\text { sivado, } \\
\text { Pagurus } \\
\text { alatus, } \\
\text { Polycheles } \\
\text { typhlops and } \\
\text { Actinauge } \\
\text { sp. }\end{array}$ & $\begin{array}{l}\text { Sandy to } \\
\text { coarser } \\
\text { sediment } \\
\text { habitats } \\
\text { scattered with } \\
\text { stones } \\
\text { displaying } \\
\text { high bed shear } \\
\text { stress and } \\
\text { depths ranging } \\
\text { between } \\
\text { 30-50 m. } \\
\text { Benthic } \\
\text { community } \\
\text { characterized } \\
\text { by Hyas, } \\
\text { Palaemon } \\
\text { serratus, } \\
\text { Buccinum }\end{array}$ \\
\hline
\end{tabular}


undatum, and Echinoidae.

H3 Muddy and sandy polyhaline habitat, characterized by Asterias, Harmothoe, and Leptonereis.

H4

H5

$\begin{array}{ll}\begin{array}{l}\text { Deep muddy } \\ \text { and sandy }\end{array} & \begin{array}{l}\text { Pebble } \\ \text { community in } \\ \text { habitat ranging } \\ \text { strong current } \\ 15-30 \mathrm{~m},\end{array} \\ \text { ander marine } & \text { dominated by } \\ \text { influence. } & \text { Ophiotrix } \\ \text { Benthic } & \text { fragilis and } \\ \text { assemblage } & \text { Pisidia } \\ \text { dominated by } & \text { longicornis. } \\ \text { Abra alba. } & \end{array}$

Muddy habitat Gravel and ranging 10-15 coarse sand $m$ displaying a habitat in benthic deeper depths assemblage (50-60 m), dominated by Sternaspis dominated by scutata Verruca stroemia, and Sabellaria spinulosa.

Heterogeneous coastal strata mostly less than 50 $m$ deep, characterized by Ophiura ophiura, Asterias rubens

Sandy and shallow habitat (10-30 m) with high bed shear stress, dominated by a community of echinoderms (Astropecten irregularis irregularis, Ophiura albida, Ophiura ophiura).

Deep (>60 m) and warm water habitat scattered with pebbles, characterized by Lithodes maja and Astropecten irregularis irregularis. irregularis, Macropipus tuberculatus

Sandy mudflats ('GrandeVasière') from 100 to $120 \mathrm{~m}$, characterized

by burrowing crustaceans

like

Nephrops norvegicus, Munida spp and Alpheus glaber 
Table 5 List of families and species regularly captured in scientific bottom trawl surveys to which special attention should be paid because they are important species structuring the megabenthic communities in the study surveys. For the complete list of morphospecies see Table S1 of Supplementary Material S1.

\begin{tabular}{|c|c|c|}
\hline Family & Species & Morphospecies \\
\hline Alpheidae & Alpheus glaber & Gr45 \\
\hline \multirow[t]{2}{*}{ Amphiuridae } & Acrocnida brachiata & Gr36 \\
\hline & Amphiura filiformis & Gr36 \\
\hline \multirow[t]{2}{*}{ Anomiidae } & Pododesmus patelliformis & Gr26 \\
\hline & Pododesmus squama & Gr26 \\
\hline \multirow[t]{2}{*}{ Antedonidae } & Antedon petasus & Gr1 \\
\hline & Leptometra celtica & Gr1 \\
\hline \multirow[t]{2}{*}{ Atelecyclidae } & Atelecyclus rotundatus & Gr21 \\
\hline & Atelecyclus undecimdentatus & Gr21 \\
\hline \multirow[t]{2}{*}{ Calliostomatidae } & Calliostoma granulatum & Gr31 \\
\hline & Calliostoma zizyphinum & Gr31 \\
\hline \multirow[t]{7}{*}{ Carcinidae } & Liocarcinus depurator & Gr19 \\
\hline & Liocarcinus holsatus & Gr19 \\
\hline & Liocarcinus marmoreus & Gr19 \\
\hline & Liocarcinus navigator & Gr19 \\
\hline & Liocarcinus pusillus & Gr19 \\
\hline & Liocarcinus vernalis & Gr19 \\
\hline & Polybius henslowii & Gr19 \\
\hline Crangonidae & Crangon allmanni & Gr18 \\
\hline
\end{tabular}


Crangon crangon Gr18

Philocheras echinulatus $\quad$ Gr18

Pontophilus spinosus $\quad$ Gr18

Discodorididae Jorunna tomentosa Gr11

Dorididae Doris pseudoargus $\quad$ Gr11

$\begin{array}{lll}\text { Inachidae } & \text { Inachus dorsettensis } & \text { Gr4 }\end{array}$

Inachus leptochirus $\quad \mathrm{Gr} 4$

Inachus phalangium $\quad \mathrm{Gr} 4$

Macropodia rostrata $\quad \mathrm{Gr} 4$

Macropodia tenuirostris Gr4

Majidae Ergasticus clouei $\quad$ Gr4

$\begin{array}{lll}\text { Naticidae } \quad \text { Euspira catena } & \text { Gr28 }\end{array}$

Euspira pulchella Gr28

Nephropidae Nephrops norvegicus Gr45

Onchidorididae Onchidoris bilamellata Gr11

$\begin{array}{lll}\text { Ophiuridae } & \text { Ophiura albida }\end{array}$

Ophiura ophiura Gr3

Pasiphaeidae Pasiphaea multidentata Gr17

Pasiphaea sivado $\quad$ Gr17

$\begin{array}{lll}\text { Pectinidae } & \text { Aequipecten opercularis } & \text { Gr20 }\end{array}$

Mimachlamys varia Gr20

$\begin{array}{lll}\text { Pharidae } & \text { Pharus legumen }\end{array}$

Phaxas pellucidus $\quad$ Gr38

$\begin{array}{lll}\text { Polynoidae } & \text { Lepidonotus clava } & \text { Gr27 }\end{array}$

Lepidonotus squamatus $\quad$ Gr27 
Gattyana cirrhosa

Sthenelais boa

Tritonia hombergi

Lamellaria perspicua
Gr27

Gr27

Gr11

Gr11

Research highlights

- This study quantifies the ecological loss of misidentifying benthic megafauna

- It suggests that the morphospecies is a good surrogate to species identification

- Bottom-trawl surveys provide reliable data to inform MSFD benthic descriptors 
Fig. 1
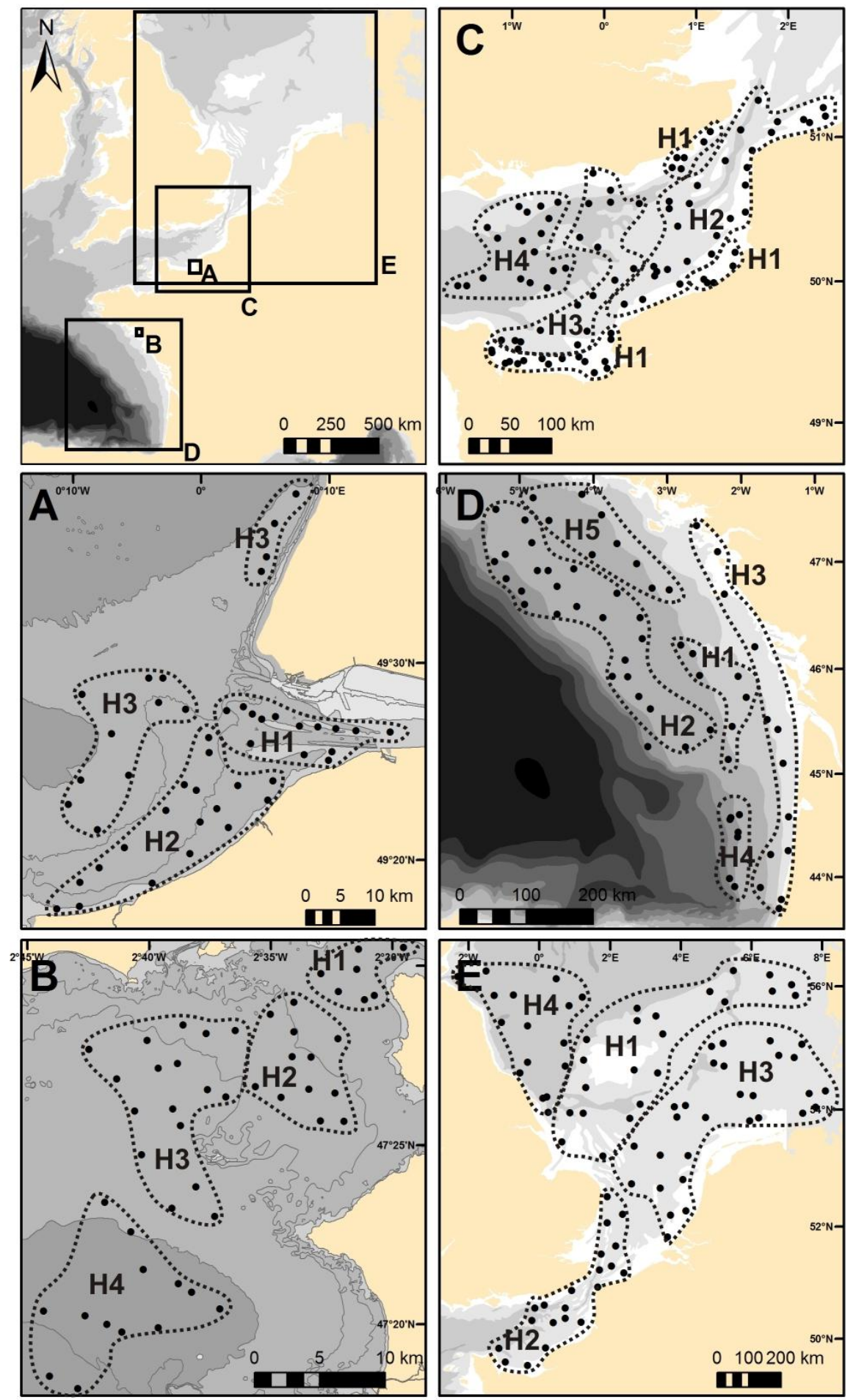
Fig. 2

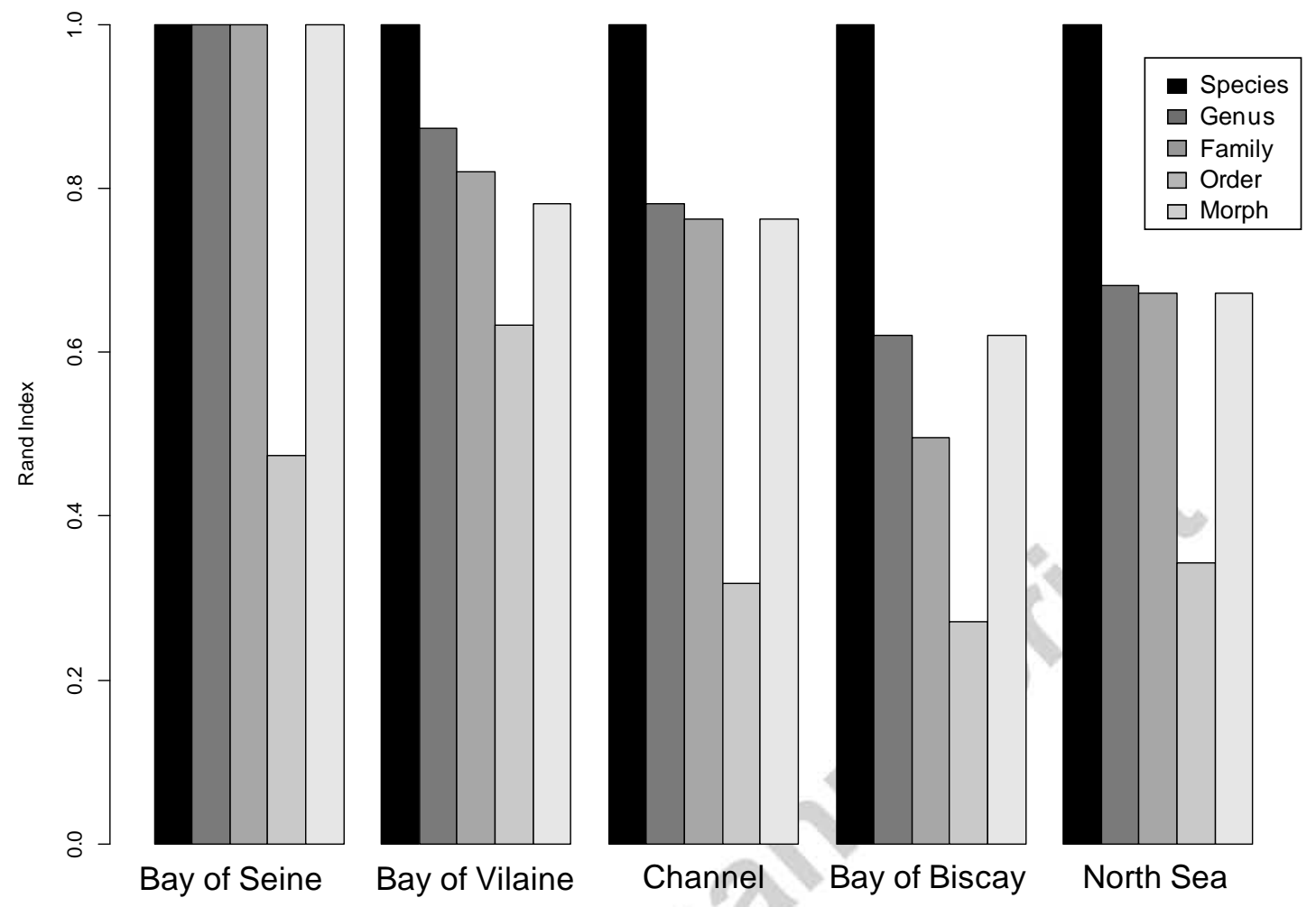



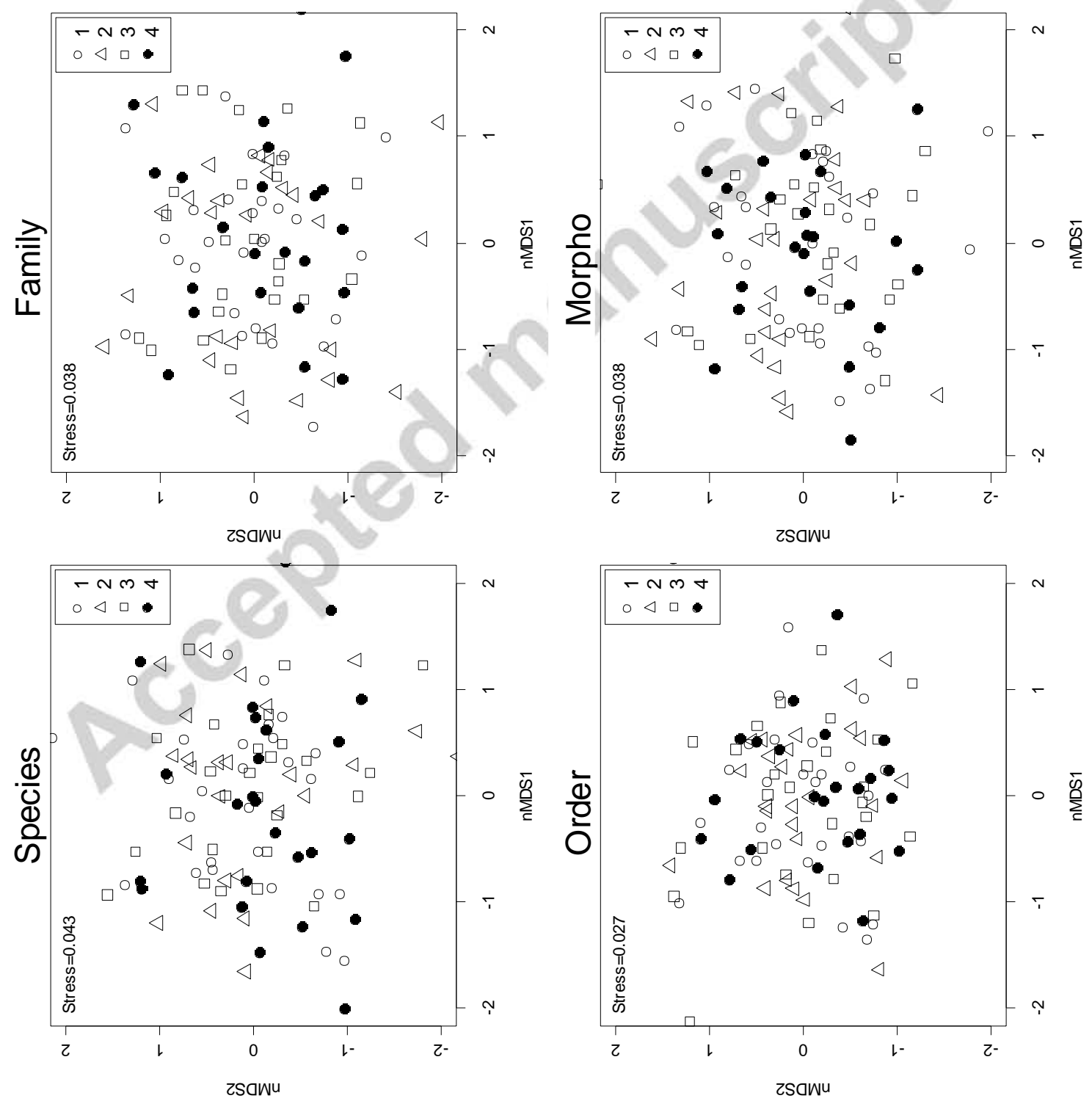

$m$

i 